Supplementary Information

\title{
Metal-free Molecular Perovskite High-energetic Materials
}

Yu Shang, Rui-Kang Huang, Shao-Li Chen, * Chun-Ting He, Zhi-Hong Yu, Zi-Ming Ye, WeiXiong Zhang* and Xiao-Ming Chen

MOE Key Laboratory of Bioinorganic and Synthetic Chemistry, School of Chemistry, Sun Yat-Sen University, Guangzhou 510275, China

* Corresponding authors (emails: chenshli8@mail.sysu.edu.cn (SLC), zhangwx6@mail.sysu.edu.cn (WXZ)) 


\section{Experimental details:}

\section{Powder X-Ray diffraction (PXRD) and Density Measurements}

The PXRD patterns $(\mathrm{Cu}-\mathrm{K} \alpha)$ for identifying the phase purity were collected on Bruker Advance D8 $\theta-2 \theta$ diffractometer by Bragg-Brentano geometry.

Capillary powder X-ray diffraction: The measurements were performed on the capillary samples on Bruker Advance D8 $\theta-2 \theta$ diffractometer at $298 \mathrm{~K}$. The powder samples were loaded in capillaries with diameter of $0.8 \mathrm{~mm}$, and then the step-scanned PXRD data were recorded in the $2 \theta$ range of 5$80^{\circ}$ with $2 \theta$ step size of $0.02^{\circ}$. The Pawley refinements for the PXRD patterns were performed on unit-cell parameters, zero point, background terms with Pseudo-Voigt profile function and BerarBaldinozzi asymmetry correction function, by using the Reflex module of Material Studio. The final Pawley refinements yielded the following parameters:

For DAP-O4, $a=b=c=14.7609$ (8) $\AA R_{\mathrm{p}}=2.58 \%$ and $R_{\mathrm{wp}}=3.50 \%$. The corresponding density is $1.845 \mathrm{~g} / \mathrm{cm}^{3}$.

For PAP-M4, $a=10.2502(0) \AA, b=14.6734(2) \AA, c=20.9489$ (6) $\AA . R_{\mathrm{p}}=1.68 \%$ and $R_{\mathrm{wp}}=2.28 \%$. The corresponding density is $1.765 \mathrm{~g} / \mathrm{cm}^{3}$.

For PAP-H4, $a=19.7513(9) \AA, b=14.3426$ (9) $\AA, c=10.7292(6) \AA . . R_{\mathrm{p}}=1.45 \%$ and $R_{\mathrm{wp}}=1.98 \%$. The corresponding density is $1.829 \mathrm{~g} / \mathrm{cm}^{3}$.

For DAP-M4, $a=10.19253(9) \AA, b=10.9913(0) \AA, c=14.8318(9) \AA . . R_{\mathrm{p}}=2.06 \%$ and $R_{\mathrm{wp}}=2.86 \%$. The corresponding density is $1.777 \mathrm{~g} / \mathrm{cm}^{3}$.

\section{The estimation on detonation performance}

To estimate the detonation performances, the following two methods were employed step by step: (1) using density functional theory (DFT) calculation and extended Kamlet-Jacob's (K-J) equation, and (2) using EXPLO5 based on enthalpy of formation back-calculated from detonation reactions. The results are listed in Table 2 and Table S3, respectively. 
(1) Using Density functional theory (DFT) calculation and extended Kamlet-Jacob's equation

DFT was employed to calculate the energy of detonation $\left(\Delta E_{\mathrm{det}}\right)$, performing with the code DMoL3 ${ }^{[\mathrm{S} 1]}$ under $3 \mathrm{D}$ periodic boundary conditions accompanied with the Monkhorst-Pack multiple K-point sampling of the Brillouin zone ${ }^{[\mathrm{S} 2]}$ and the Perdew-Becke-Ezerhoff (PBE) exchangecorrelation function ${ }^{[\mathrm{S} 3]}$. The heat of detonation $\left(\Delta H_{\mathrm{det}}\right)$ was estimated from $\Delta E_{\mathrm{det}}$ by a linear correlation equation $^{[36]}$ :

$$
\Delta H_{\mathrm{det}}=1.127 \Delta E_{\mathrm{det}}+0.046, \mathrm{r}=0.968 . \quad \text { Eq. } \mathrm{S} 1
$$

Detonation velocity and pressure were estimated by a method using extended Kamlet-Jacob's equation for explosives ${ }^{[\mathrm{S} 4]}$ :

$$
\begin{array}{ll}
D=1.01 \Phi^{1 / 2}(1+1.30 \rho) & \text { Eq. } \mathrm{S} 2 \\
P=1.558 \Phi \rho^{2} & \text { Eq. } \mathrm{S} 3 \\
\Phi=31.68 N(M Q)^{1 / 2} & \text { Eq. S4 }
\end{array}
$$

Here, $\rho$ represents the density of explosive $\left(\mathrm{g} \mathrm{cm}^{-3}\right), N$ and $M$ are the characteristic parameters of the detonation products, $N$ is the moles of detonation gases per gram of explosive and $M$ is the average molecular weight of these gases, $Q$ is the heat of detonation $\left(\Delta H_{\text {det }}, \mathrm{kcal} \mathrm{g}^{-1}\right), D$ is the detonation velocity $\left(\mathrm{km} \mathrm{s}^{-1}\right)$, and $P$ is the detonation pressure (GPa).

According to literature ${ }^{[S 4]}$, the detonation products can be described as dinitrogen, water, carbon dioxide, carbon and hydrogen chloride. Accordingly, the complete detonation reactions are as follows:

For RDX, $\mathrm{C}_{3} \mathrm{H}_{6} \mathrm{~N}_{6} \mathrm{O}_{6}=3 \mathrm{H}_{2} \mathrm{O}(\mathrm{g})+3 \mathrm{~N}_{2}(\mathrm{~g})+1.5 \mathrm{CO}_{2}(\mathrm{~g})+1.5 \mathrm{C}(\mathrm{s})$

For $\beta-\mathrm{HMX}, \mathrm{C}_{4} \mathrm{H}_{8} \mathrm{~N}_{8} \mathrm{O}_{8}=4 \mathrm{H}_{2} \mathrm{O}(\mathrm{g})+4 \mathrm{~N}_{2}(\mathrm{~g})+2 \mathrm{CO}_{2}(\mathrm{~g})+2 \mathrm{C}(\mathrm{s})$

For $\varepsilon-\mathrm{CL}-20, \mathrm{C}_{6} \mathrm{H}_{6} \mathrm{~N}_{12} \mathrm{O}_{12}=3 \mathrm{H}_{2} \mathrm{O}(\mathrm{g})+6 \mathrm{~N}_{2}(\mathrm{~g})+4.5 \mathrm{CO}_{2}(\mathrm{~g})+1.5 \mathrm{C}(\mathrm{s})$

For DAP-4, $\left(\mathrm{C}_{6} \mathrm{H}_{14} \mathrm{~N}_{2}\right)\left[\mathrm{NH}_{4}\left(\mathrm{ClO}_{4}\right)_{3}\right]=3 \mathrm{HCl}(\mathrm{g})+7.5 \mathrm{H}_{2} \mathrm{O}(\mathrm{g})+1.5 \mathrm{~N}_{2}(\mathrm{~g})+2.25 \mathrm{CO}_{2}(\mathrm{~g})+3.75 \mathrm{C}(\mathrm{s})$

For DAP-O4, $\left(\mathrm{C}_{6} \mathrm{H}_{14} \mathrm{~N}_{2} \mathrm{O}\right)\left[\mathrm{NH}_{4}\left(\mathrm{ClO}_{4}\right)_{3}\right]=3 \mathrm{HCl}(\mathrm{g})+7.5 \mathrm{H}_{2} \mathrm{O}(\mathrm{g})+1.5 \mathrm{~N}_{2}(\mathrm{~g})+2.75 \mathrm{CO}_{2}(\mathrm{~g})+3.25 \mathrm{C}(\mathrm{s})$

For PAP-4, $\left(\mathrm{C}_{4} \mathrm{H}_{12} \mathrm{~N}_{2}\right)\left[\mathrm{NH}_{4}\left(\mathrm{ClO}_{4}\right)_{3}\right]=3 \mathrm{HCl}(\mathrm{g})+6.5 \mathrm{H}_{2} \mathrm{O}(\mathrm{g})+1.5 \mathrm{~N}_{2}(\mathrm{~g})+2.75 \mathrm{CO}_{2}(\mathrm{~g})+1.25 \mathrm{C}(\mathrm{s})$

For PAP-M4, $\left(\mathrm{C}_{5} \mathrm{H}_{14} \mathrm{~N}_{2}\right)\left[\mathrm{NH}_{4}\left(\mathrm{ClO}_{4}\right)_{3}\right]=3 \mathrm{HCl}(\mathrm{g})+7.5 \mathrm{H}_{2} \mathrm{O}(\mathrm{g})+1.5 \mathrm{~N}_{2}(\mathrm{~g})+2.25 \mathrm{CO}_{2}(\mathrm{~g})+2.75 \mathrm{C}(\mathrm{s})$

For PAP-H4, $\left(\mathrm{C}_{5} \mathrm{H}_{14} \mathrm{~N}_{2}\right)\left[\mathrm{NH}_{4}\left(\mathrm{ClO}_{4}\right)_{3}\right]=3 \mathrm{HCl}(\mathrm{g})+7.5 \mathrm{H}_{2} \mathrm{O}(\mathrm{g})+1.5 \mathrm{~N}_{2}(\mathrm{~g})+2.25 \mathrm{CO}_{2}(\mathrm{~g})+2.75 \mathrm{C}(\mathrm{s})$

For DAP-M4, $\left(\mathrm{C}_{7} \mathrm{H}_{16} \mathrm{~N}_{2}\right)\left[\mathrm{NH}_{4}\left(\mathrm{ClO}_{4}\right)_{3}\right]=3 \mathrm{HCl}(\mathrm{g})+8.5 \mathrm{H}_{2} \mathrm{O}(\mathrm{g})+1.5 \mathrm{~N}_{2}(\mathrm{~g})+1.75 \mathrm{CO}_{2}(\mathrm{~g})+5.25 \mathrm{C}(\mathrm{s})$ 
The real detonation reactions are very complicated. The above calculation could only roughly estimate the detonation performances as it is based on assumed detonation reaction and empirical $\mathrm{K}-\mathrm{J}$ equation. It is necessary to accurately measure the detonation parameters by experiments for molecular perovskite materials in the next stage.

Table S1. Calculated (DMoL3/PBE) total energy (hartree) used in the detonation reactions

\begin{tabular}{ccccccccc}
\hline Compound & RDX & $\beta$-HMX & $\varepsilon$-CL-20 & DAP-4 & DAP-O4 & PAP-4 & PAP-M4 & PAP-H4 \\
\hline $\begin{array}{c}\text { Total energy } \\
\text { (hartree) }\end{array}$ & -896.924 & -1195.900 & 1790.220 & 2684.997 & 2760.113 & 2607.680 & 2647.040 & 2646.951 \\
\hline Compound & DAP-M4 & $\mathrm{N}_{2}$ & $\mathrm{H}_{2} \mathrm{O}$ & $\mathrm{CO}_{2}$ & $\mathrm{HCl}$ & $\mathrm{C}$ & $\mathrm{H}_{2}$ & \\
\hline $\begin{array}{c}\text { Total energy } \\
\text { (hartree) }\end{array}$ & 2724.368 & -109.449 & -76.379 & -188.479 & -460.638 & -38.084 & -1.164 & \\
\hline
\end{tabular}

1 hartree $=627.51 \mathrm{kcal} \cdot \mathrm{mol}^{-1}$

(2) Using EXPLO5 Based on enthalpy of formation (HOF) be back-calculated from detonation reactions

Since the combustion product hydrochloric acid can corrode the container, producing extra heat release, the heat of formations of halogen-containing compounds measured by oxygen bomb calorimetry were generally overestimated as well as the calculated explosive performances. Alternately, we estimated the enthalpies of formation from heat of explosion $\left(\Delta H_{\mathrm{det}}\right)$ on the basis of assumed detonation reaction obtained by method (1) and with the Hess law. ${ }^{[S 4]}$ The enthalpies of detonation reaction were calculated according to the formula $\Delta_{\mathrm{c}} H=\Delta H_{\mathrm{det}}+n R T,(n=n$ (gaseous products) $-n$ (gaseous reactants), $R=8.314 \mathrm{~J} \mathrm{~mol}^{-1} \mathrm{~K}^{-1}$ and $T=298.15 \mathrm{~K}$ ). Based on the calculated enthalpies of detonation reaction and the known enthalpies of formation of the products, the enthalpies of formation can be calculated from the relevant detonation reactions for molecular perovskite compounds. For the convenience of comparison, some well-known explosives such as RDX, $\beta$-HMX and $\varepsilon$-CL-20 were also calculated by the same method, and the results are listed in Table S2. 
Table S2. The enthalpies of formation of six metal-free molecular perovskite compounds, wellknown explosives, and the relevant combustion products.

\begin{tabular}{cccc}
\hline Compound & $\Delta H_{\text {det }}\left(\mathrm{kJ} \mathrm{mol}^{-1}\right)$ & $\Delta_{\mathrm{c}} H\left(\mathrm{~kJ} \mathrm{~mol}^{-1}\right)$ & $\Delta_{\mathrm{f}} H\left(\mathrm{~kJ} \mathrm{~mol}^{-1}\right)$ \\
\hline RDX & -1241.63 & -1223.04 & -92.70 \\
$\beta-\mathrm{HMX}$ & -1652.55 & -1627.76 & -126.57 \\
$\varepsilon^{-} \mathrm{CL}-20$ & -2729.91 & -2696.44 & 200.17 \\
DAP-4 & -2527.39 & -2492.06 & -483.96 \\
DAP-O4 & -2773.26 & -2736.70 & -436.08 \\
PAP-4 & -2427.36 & -2393.28 & -537.68 \\
PAP-M4 & -2151.45 & -2116.13 & -859.90 \\
PAP-H4 & -2410.96 & -2375.64 & -600.38 \\
DAP-M4 & -2218.60 & -2182.04 & -839.05 \\
$\mathrm{CO}_{2}(g)$ & $/$ & $/$ & $-393.51^{\mathrm{a}}$ \\
$\mathrm{H}_{2} \mathrm{O}(g)$ & $/$ & $/$ & $-241.826^{\mathrm{a}}$ \\
$\mathrm{N}_{2}(g)$ & $/$ & $/$ & $0^{\mathrm{a}}$ \\
$\mathrm{HCl}(g)$ & $/$ & $/$ & $-92.31^{\mathrm{a}}$ \\
\hline
\end{tabular}

a) The enthalpies of formation $\left(\Delta_{\mathrm{f}} H\right)$ of the products were derived from NIST.

Table S3. Detonation properties estimated by using EXPLO5 v6.04.02 for some well-known explosives and six metal-free molecular perovskite high-energetic materials.

\begin{tabular}{cccccccccc}
\hline Compound & $\begin{array}{c}\rho \\
\left(\mathrm{g} \mathrm{cm}^{-1}\right)\end{array}$ & $\begin{array}{c}\left.\Delta H_{\mathrm{f}}^{\mathrm{c}}\right) \\
\left(\mathrm{kJ} \mathrm{mol}^{-1}\right)\end{array}$ & $\begin{array}{c}Q^{\mathrm{d})} \\
\left(\mathrm{kJ} \mathrm{g}^{-1}\right)\end{array}$ & $\begin{array}{c}D^{\mathrm{d})} \\
\left(\mathrm{km} \mathrm{s}^{-1}\right)\end{array}$ & $\begin{array}{c}P^{\mathrm{d})} \\
(\mathrm{GPa})\end{array}$ & $\begin{array}{c}I_{\mathrm{sp}}^{\mathrm{d})} \\
(\mathrm{s})\end{array}$ & $\begin{array}{c}\mathrm{OB}^{\mathrm{e})} \\
(\%)\end{array}$ & $\begin{array}{c}\mathrm{IS}^{\mathrm{f})} \\
(\mathrm{J})\end{array}$ & $\begin{array}{c}\mathrm{FS}^{\mathrm{g})} \\
(\mathrm{N})\end{array}$ \\
\hline RDX & $1.82^{\mathrm{a})}$ & -92.70 & 5.07 & 8.657 & 33.2 & 251.0 & -21.6 & $7.5^{\mathrm{h})}$ & $120^{\mathrm{h})}$ \\
$\beta^{-H M X}$ & $1.90^{\mathrm{a})}$ & -126.57 & 5.08 & 8.929 & 36.5 & 250.7 & -21.6 & $7^{\mathrm{h})}$ & $112^{\mathrm{h})}$ \\
$\varepsilon^{-}$CL-20 & $2.04^{\mathrm{a})}$ & 200.17 & 5.80 & 9.467 & 44.2 & 264.7 & -11.0 & $4^{\mathrm{h})}$ & $48^{\mathrm{h})}$ \\
DAP-4 & $1.87^{\mathrm{b})}$ & -483.96 & 5.25 & 8.195 & 31.2 & 253.6 & -27.9 & 23 & 36 \\
DAP-O4 & $1.85^{\mathrm{b})}$ & -436.08 & 5.56 & 8.255 & 32.1 & 262.5 & -23.3 & 17.5 & $<5$ \\
PAP-4 & $1.74^{\mathrm{b})}$ & -537.68 & 5.50 & 7.950 & 28.0 & 264.2 & -9.9 & $/$ & $/$ \\
PAP-M4 & $1.77^{\mathrm{b})}$ & -859.90 & 4.59 & 7.761 & 26.7 & 241.3 & -21.0 & 30 & $\leq 6$ \\
PAP-H4 & $1.83^{\mathrm{b})}$ & -600.38 & 5.19 & 8.136 & 30.4 & 255.3 & -21.0 & 27.5 & 6 \\
DAP-M4 & $1.78^{\mathrm{b})}$ & -839.05 & 4.37 & 7.608 & 25.1 & 225.3 & -37.8 & 7.5 & 10 \\
\hline
\end{tabular}

a) The crystal densities reported in Ref. 3; b) The crystal densities measured by capillary powder X-ray diffraction at room temperature, except that of PAP-4 measured by single-crystal X-ray diffraction at $\left.298 \mathrm{~K} ;{ }^{c}\right) \Delta H_{\mathrm{f}}$ is the heat of formation back-calculated from assumed detonation reactions obtained by method (1); ${ }^{\text {d) }} Q$ is the heat of detonation, $D$ is the detonation velocity, $P$ is the detonation pressure, and $I_{\mathrm{sp}}$ is the specific impulses. The detonation parameters were calculated by EXPLO5 v6.04.02 code; ${ }^{\text {e) }}$ Oxygen Balance based on $\mathrm{CO}_{2}$ for $\mathrm{C}_{\mathrm{a}} \mathrm{H}_{\mathrm{b}} \mathrm{N}_{\mathrm{c}} \mathrm{Cl}_{\mathrm{d}} \mathrm{O}_{\mathrm{e}}$ : OB[\%] $=1600[\mathrm{e}-2 a-(b-d) / 2] / M_{W}$, where $M_{W}$ is molecular weight; ${ }^{\mathrm{f})}$ Impact sensitivity; g) Friction sensitivity; ${ }^{\text {h) }}$ The impact and friction sensitivity reported in Ref. 17.

\section{The HOF of $\mathrm{H}_{2} \mathrm{mpz}^{2+}$ and $\mathrm{H}_{2} \mathrm{hpz}^{2+}$}

The HOF of the gas phase of $\mathrm{H}_{2} \mathrm{mpz}^{2+}$ and $\mathrm{H}_{2} \mathrm{hpz}^{2+}$ cations were calculated by using Gaussian 09 program. ${ }^{[55]}$ The structures were geometrically optimized and the frequency was analyzed using 
a B3LYP function with a $6-31+\mathrm{G}^{* *}$ basis set. ${ }^{[\mathrm{S6}]}$ Single-point energies were calculated at the MP2(full)/6-311++G** level. The representative reactions are shown in Scheme S1. All of the optimized structures were characterized as true local energy minima on the potential-energy surface without imaginary frequencies. The calculated total energy $\left(E_{0}\right)$, zero-point energy (ZPE), other thermal factors and HOFs of the cations are obtained in Table S4.
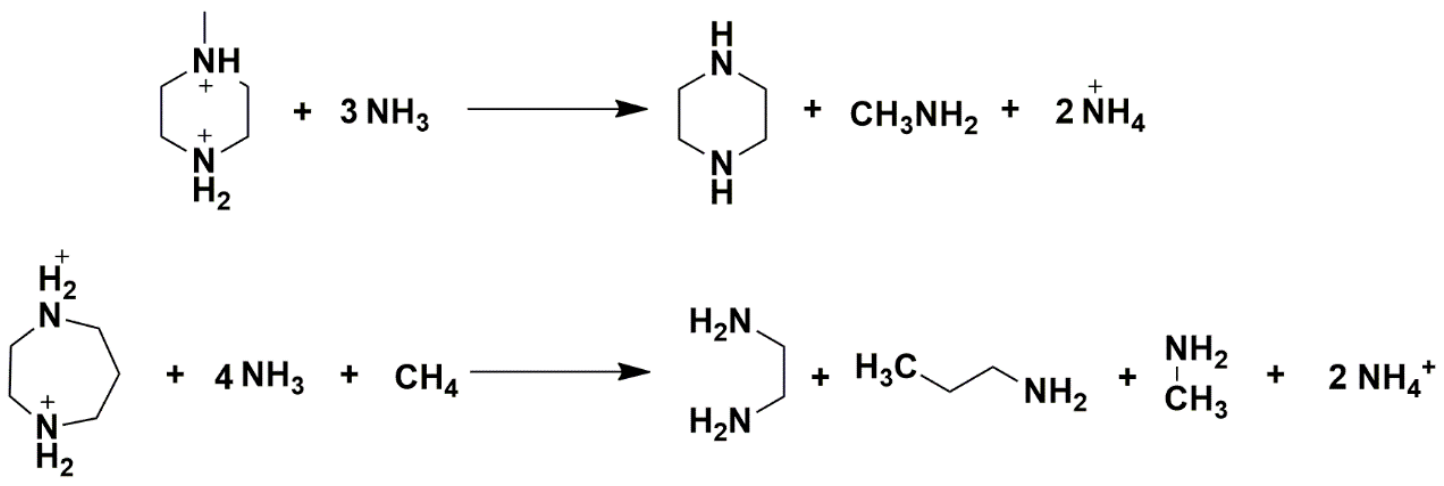

Scheme S1. Isodesmic reaction schemes for $\mathrm{H}_{2} \mathrm{mpz}^{2+}$ and $\mathrm{H}_{2} \mathrm{hpz}{ }^{2+}$ cations.

Table S4. Calculated (B3LYP/6-31++G**//MP2/6-311++G**) total energy $\left(E_{0}\right)$, zero-point energy (ZPE), values of thermal correction $\left(H_{\mathrm{T}}\right)$, and heats of formation $(\mathrm{HOF})$ of the selected cations.

\begin{tabular}{ccccc}
\hline Name & $\boldsymbol{E}_{\mathbf{0}}$ (hartree) & ZPE (hartree) & $\boldsymbol{H}_{\mathbf{T}}$ (hartree) & HOF $(\mathbf{K J} / \mathbf{m o l})$ \\
\hline $\mathrm{H}_{2} \mathrm{mpz}^{2+}$ & -307.71923 & 0.204612 & 0.008005 & 1555.9 \\
$\mathrm{H}_{2} \mathrm{hpz}^{2+}$ & -307.721896 & 0.205807 & 0.007964 & 1558.6 \\
Piperazine & -267.862701 & 0.147024 & 0.006476 & $25.0^{\mathrm{a})}$ \\
$\mathrm{NH}_{2} \mathrm{CH}_{2} \mathrm{CH}_{2} \mathrm{NH}_{2}$ & -190.473328 & 0.109076 & 0.005608 & $-17.0^{\mathrm{a})}$ \\
$\mathrm{CH}_{3} \mathrm{CH}_{2} \mathrm{CH}_{2} \mathrm{NH}_{2}$ & -174.423197 & 0.120166 & 0.006172 & $-69 .^{\text {a) }}$ \\
$\mathrm{NH}_{3}$ & -56.548469 & 0.034253 & 0.003817 & $-45.9^{\mathrm{a}}$ \\
$\mathrm{NH}_{4}^{+}$ & -56.870878 & 0.049477 & 0.003796 & $\left.626.4^{\mathrm{a}}\right)$ \\
$\mathrm{CH}_{3} \mathrm{NH}_{2}$ & -95.830097 & 0.063793 & 0.004377 & $-23.0^{\mathrm{a})}$ \\
\hline
\end{tabular}

a) The enthalpies of formation (HOF) of the products were derived from NIST.

\section{Impact and friction sensitivities}

The impact and friction sensitivities of these metal-free perovskite energetic materials were evaluated using a standard BFH 10 BAM impact apparatus and a FSKM 10 BAM friction apparatus, respectively. As listed in Table 2, the DAP-M4 shows the impact sensitivity of $7.5 \mathrm{~J}$, which is comparable to the typical high explosives such as RDX (IS = $7.5 \mathrm{~J}$ ) and $\beta-\mathrm{HMX}$ (IS $=7 \mathrm{~J}$ ). The impact sensitivities of other metal-free perovskite energetic materials ranges from 17.5 to $30 \mathrm{~J}$, 
which are lower than those for RDX, $\beta-\mathrm{HMX}$ and $\varepsilon^{-\mathrm{CL}}-20$ and comparable to TNT. Friction sensitivity tests show that these metal-free perovskite energetic materials are generally sensitive to friction, which range from 5 to $10 \mathrm{~N}$, not as insensitive as even HMX and RDX.

Table S5. Selected inter-atomic distances $(\AA)$ in six metal-free molecular perovskites.

\begin{tabular}{ccccccc}
\hline & PAP-4 & PAP-M4 & PAP-H4 & DAP-O4 & DAP-M4 & DAP-4 \\
\hline average $\mathrm{N} 1-\mathrm{O}^{\mathrm{a})}$ & 3.030 & 3.207 & 3.037 & 3.076 & 3.133 & 3.038 \\
average $\mathrm{N} 2-\mathrm{O}$ & $/$ & 3.093 & 3.052 & $/$ & 3.137 & 3.001 \\
average $\mathrm{N} 3-\mathrm{O}$ & $/$ & $/$ & 3.040 & $/$ & $/$ & $/$ \\
average $\mathrm{N} 4-\mathrm{O}$ & $/$ & $/$ & 3.045 & $/$ & $/$ & $/$ \\
average $\mathrm{N}-\mathrm{O}$ & 3.030 & 3.150 & 3.044 & 3.076 & 3.135 & 3.020 \\
average $\mathrm{N} 1 \cdots \mathrm{Cl}$ & 3.641 & 3.825 & 3.630 & 3.691 & 3.741 & 3.627 \\
average $\mathrm{N} 2 \cdots \mathrm{Cl}$ & $/$ & 3.690 & 3.644 & $/$ & 3.734 & 3.596 \\
average $\mathrm{N} 3 \cdots \mathrm{Cl}$ & $/$ & $/$ & 3.633 & $/$ & $/$ & $/$ \\
average $\mathrm{N} 4 \cdots \mathrm{Cl}$ & $/$ & $/$ & 3.638 & $/$ & $/$ & $/$ \\
average $\mathrm{N} \cdots \mathrm{Cl}$ & 3.641 & 3.757 & 3.636 & 3.691 & 3.737 & 3.611 \\
\hline
\end{tabular}

a) $\mathrm{N}$ and $\mathrm{O}$ atoms from $\mathrm{NH}_{4}^{+}$and $\mathrm{ClO}_{4}^{-}$, respectively; b) From reference 47.

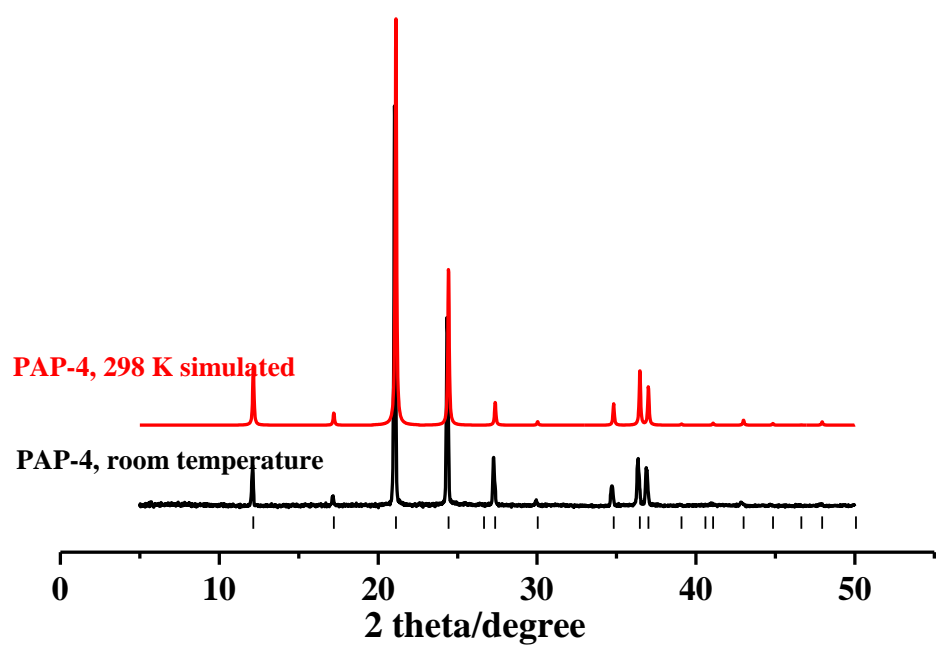

Figure S1. PXRD patterns of PAP-4. 


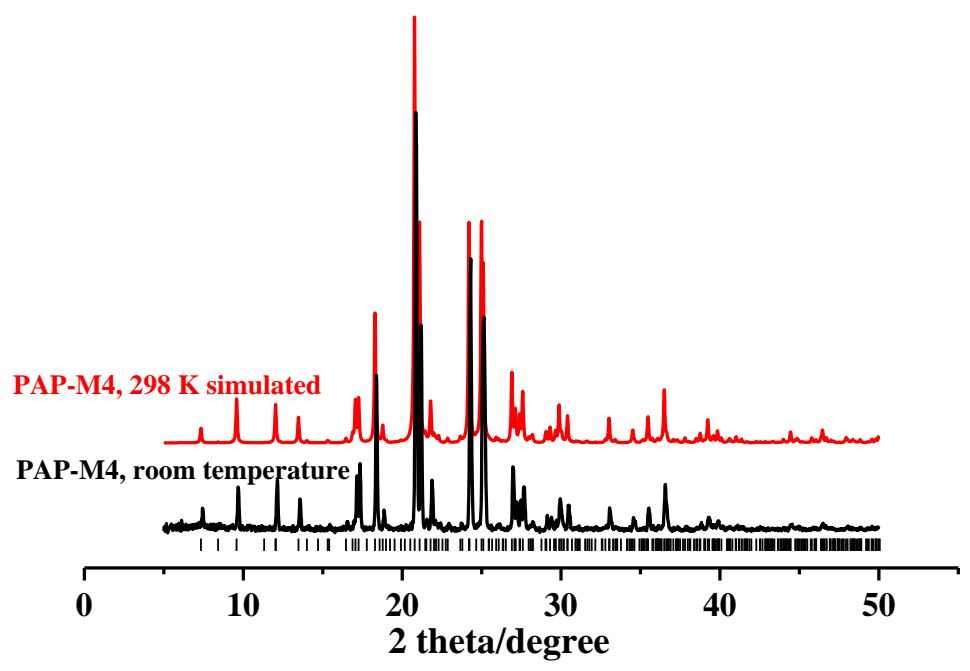

Figure S2. PXRD patterns of PAP-M4.

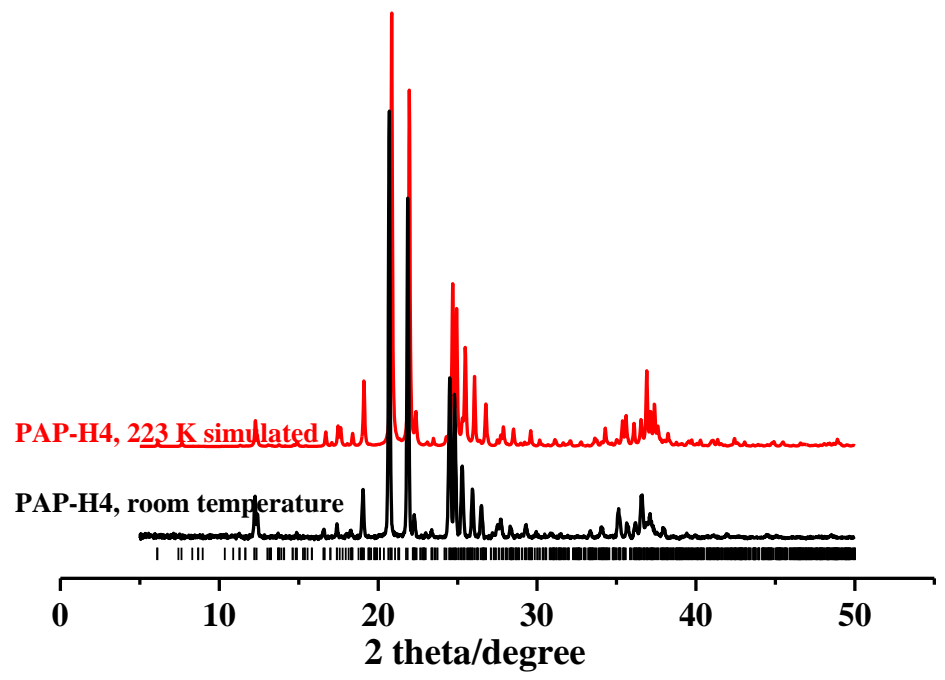

Figure S3. PXRD patterns of PAP-H4. 


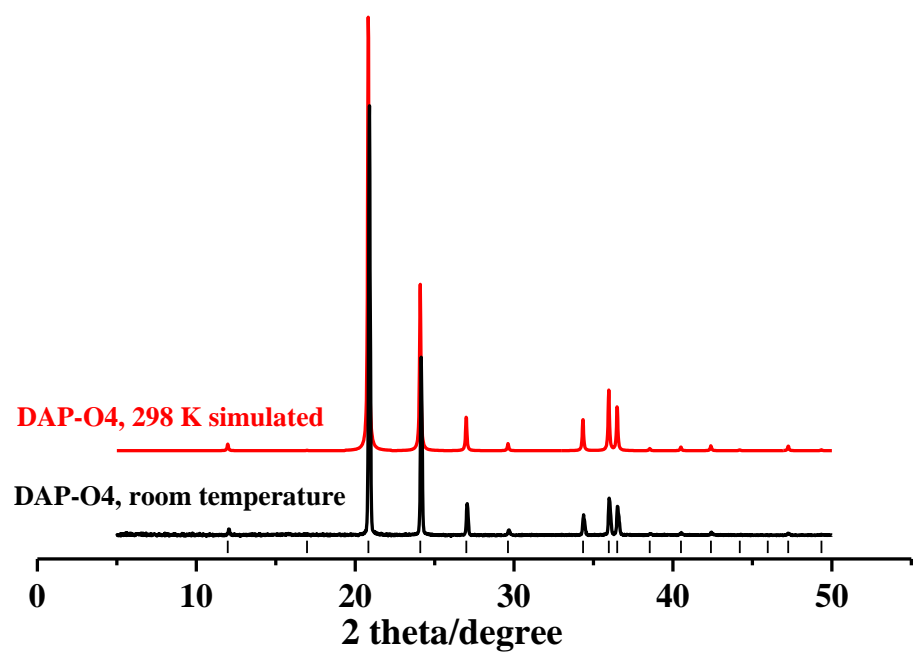

Figure S4. PXRD patterns of DAP-O4.

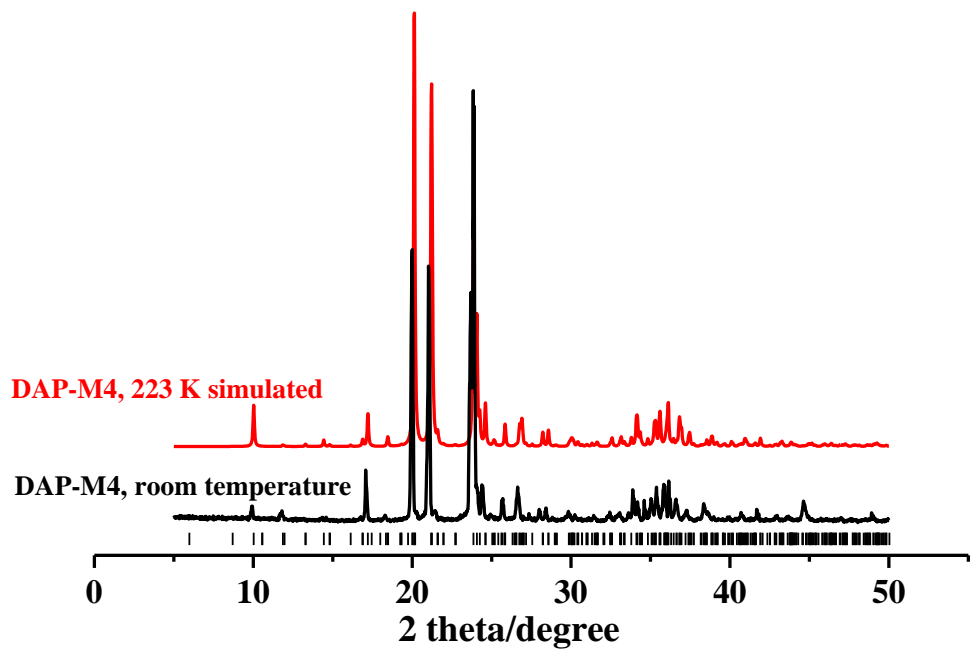

Figure S5. PXRD patterns of DAP-M4. 


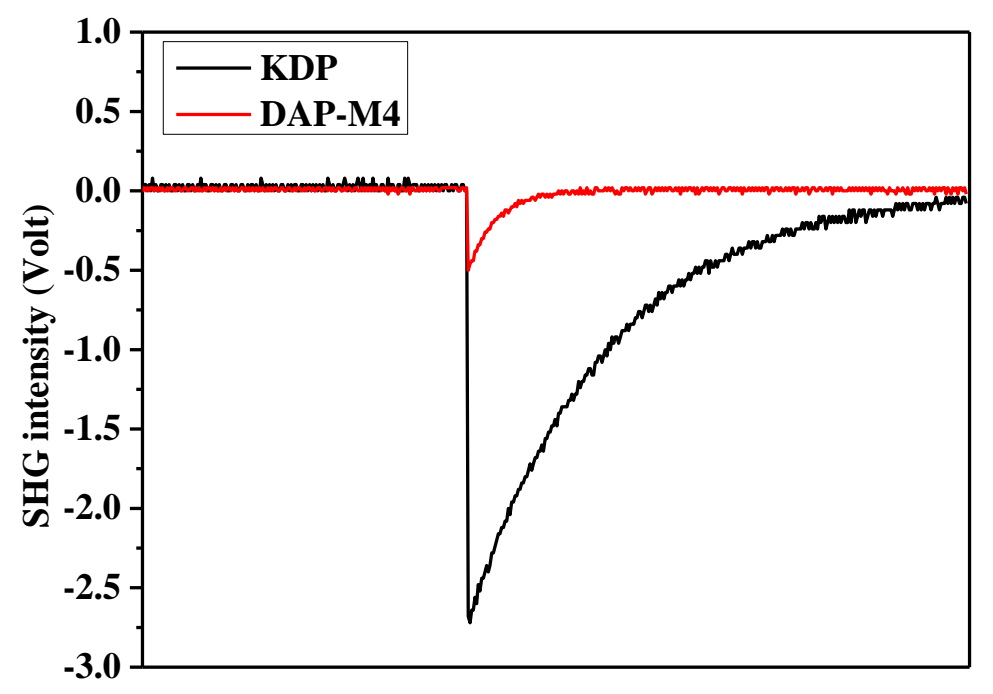

Figure S6. The comparison of NLO intensities of DAP-M4 and KDP.

\section{References:}

[S1] B. Delley. J. Chem. Phys., 1990, 92, 508-517.

[S2] H. J. Monkhorst, J. D. Pack. Phys. Rev. B, 1976, 13, 5188.

[S3] J. P. Perdew, K. Burke, M. Ernzerhof. Phys. Rev. Lett., 1996, 77, 3865.

[S4] Y. Wang, J. Zhang, H. Su, S. Li, S. Zhang, S. Pang. J. Phys. Chem. A, 2014, 118, 4575-4581.

[S5] M. Frisch, G. Trucks, H. B. Schlegel, G. E. Scuseria, M. A. Robb, J. R. Cheeseman, G. Scalmani, V. Barone, B. Mennucci, G. Petersson. Inc., Wallingford, CT, 2009, 200.

[S6] R. G. Parr, W. Yang. Density-Functional Theory of Atoms and Molecules, vol. 16 of International series of monographs on chemistry. 1989. 